\title{
Resveratrol supplementation protects against chronic nicotine-induced oxidative damage and organ dysfunction in the rat urogenital system
}

\author{
Hale Toklu¹, Özer Şehirli' ${ }^{1}$, Hülya Şahin ${ }^{2}$, Şule Çetinel$^{3}$, Berrak C. Yeğen ${ }^{4}$, Göksel Şener ${ }^{1}$
}

\begin{abstract}
The protective effect of resveratrol against nicotine induced oxidative damage on urogenital tissues was evaluated by biochemical, histological and functional studies. Wistar Albino rats were injected with either nicotine hydrogen bitartarate $(0.6 \mathrm{mg} / \mathrm{kg} / \mathrm{day}$, ip) or saline. Resveratrol (10 $\mathrm{mg} / \mathrm{kg}$, po) was administered along with saline or nicotine injections for 28 days. After decapitation, the urinary bladder, corpus cavernosum and kidney tissues were excised. Corpus cavernosum and bladder tissues were used for in vitro contractility studies, or stored at -80 으 along with kidney tissue for the measurement of malondialdehyde (MDA), glutathione (GSH), and luminol-lucigenin chemiluminescence (CL) levels. Tissue samples were also examined histologically. Chronic nicotine administration caused a significant decrease in GSH levels and increases in MDA levels, and luminol-lucigenin CL in kidney, urinary bladder and corpus cavernosum tissues, suggesting oxidative organ damage, which was also verified histologically. In serum samples increased blood urea nitrogen (BUN), creatinine, proinflammatory cytokines (TNF- $\alpha$ and IL-1 $\beta$ ), lactate dehydrogenase (LDH) activity, oxidative DNA damage (8-OHdG) and decreased antioxidant capacity (AOC) due to nicotine administration were reversed with resveratrol. Furthermore, chronic nicotine administration impaired the contractile activity of the bladder and corpus cavernosum strips while resveratrol supplementation to nicotine-treated animals reversed these effects in both tissues. Resveratrol treatment to the nicotine group restored the endogenous GSH levels and decreased oxidative damage parameters in all studied tissues. These data suggest that resveratrol supplementation effectively counteracts the deleterious effect of chronic nicotine administration on bladder, corpus cavernosum and kidney functions and attenuates oxidative damage possibly by its antioxidant effects.
\end{abstract}

KEY WORDS: resveratrol; nicotine; kidney; urinary bladder; corpus cavernosum; oxidative damage

\section{INTRODUCTION}

Tobacco smoking is one of the leading causes of death in both the developed and the developing countries (1). Among numerous harmful substances in tobacco, the primary addictive substance is nicotine. Nicotine, a water-soluble alkaloid which may be acquired through active and passive smoking, is rapidly absorbed through the respiratory tract, gastrointestinal tract, skin and mucous membranes and it is mainly metabolized in the liver (2). Experiments have shown that chronic administration of nicotine causes increased lipid peroxidation products in the serum and various tissues of rats $(3,4)$. Oxidative cellular damage due to nicotine-induced chronic inflammation is associated with generation of reactive oxygen species in the periphery and central nervous system resulting in an imbalance in the cellular oxidant-antioxidant system (5-8).

Resveratrol is a potent member of the class of natural, plant-derived chemicals known as poly-
AFFILIATIONS

${ }^{1}$ Marmara University School of Pharmacy, Pharmacology, Istanbul, Türkiye

2Marmara University

Vocational School of

Health Related Professions,

Istanbul, Türkiye

3Marmara University School

of Medicine, Histology

\& Embryology, Istanbul,

Türkiye

4Marmara University School

of Medicine, Physiology,

Istanbul, Türkiye

CORRESPONDENCE

Hale Toklu

E-mail:

haletoklu@yahoo.com

Received:

June 23, 2009

Revision:

September 23, 2009

Accepted:

September 23, 2009 
a)

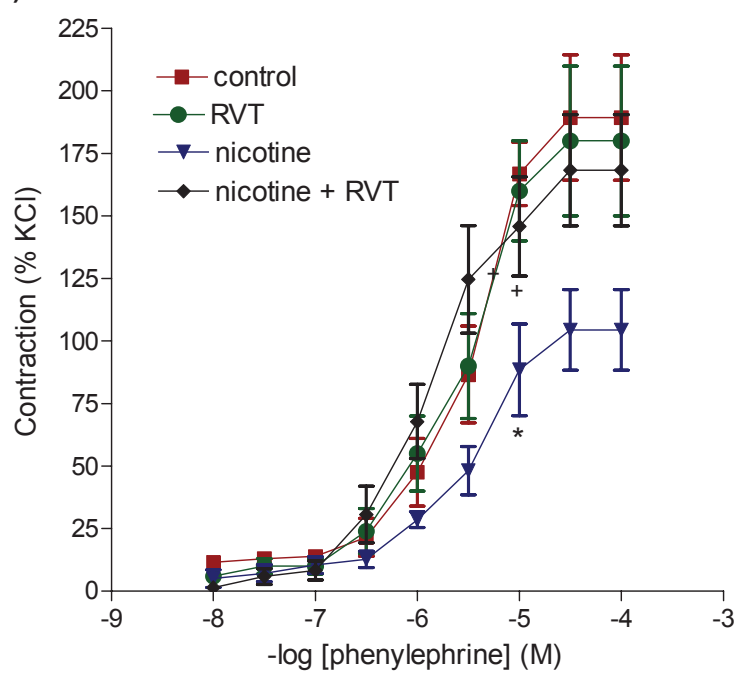

b)

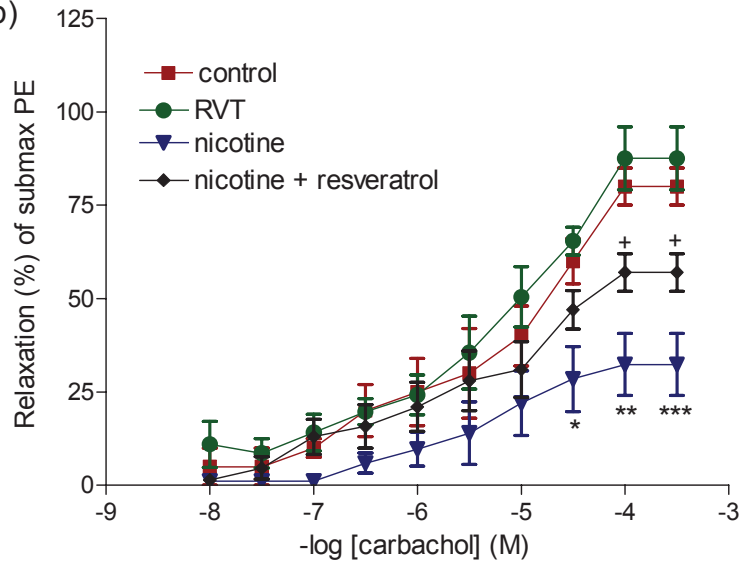

c)

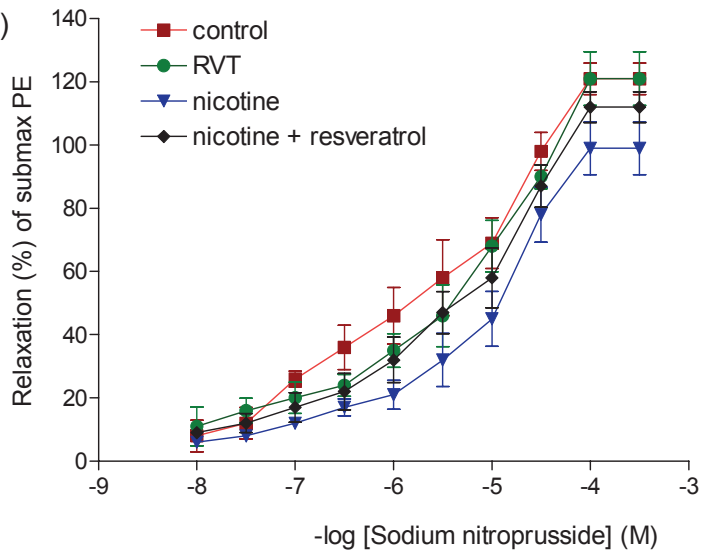

FIGURE 1. Concentration- response curve obtained by cumulative addition of a) phenylephrine b) carbachol (CCh) and c) sodium nitroprusside to corpus cavernosum strips. Values are shown as mean \pm SEM of eight experiments. ${ }^{*} p<0.05$, ${ }^{* *} \mathrm{p}<0.01,{ }^{* * *} \mathrm{p}<0.001$ compared with saline-treated control group. $+\mathrm{p}<0.05$, compared with saline-treated nicotine group. Data are given as mean \pm SEM and each group consists of 8 rats.

phenols, which are synthesized by a wide diversity of plants, such grapes, raspberries, mulberries, pistachios and peanuts, in response to stress, injury, ultraviolet irradiation and fungal infection as part of their defense mechanism (9). Polyphenols have a variety of biological functions, including antioxidant, anti-inflammatory, and anticancer effects (10-13). Resveratrol protects the cardiovascular system by exerting a positive effect on both the progression and regression of atherosclerosis, by inhibiting low-density lipoprotein (LDL) oxidation and blood platelet aggregation. Experimental studies have shown that this natural product possesses anti-inflammatory properties and inhibits the growth of some tumors (14-17).

Cigarette smoking in males has been implicated as a cause of decreased sperm numbers and an increased frequency of abnormal sperm morphology as well as a decrease in sexual performance (18). Clinical and basic science studies provide strong indirect evidence that smoking may affect penile erection by the impairment of endothelium-dependent smooth muscle relaxation via increased ROS generation (19). Several studies have documented that smoking increases the risk of developing urinary tract cancers (20-22) and the risk for end-stage renal failure in patients with renal disease (23). Recently, several studies have shown that resveratrol exerts protective effects on acute nephrotoxicity in rats (24-27) and mice (28) by suppressing the inflammatory processes and by inhibiting lipid peroxidation. Moreover, resveratrol has a positive effect on male reproductive function by triggering penile erection, as well as enhancing blood testosterone levels, testicular sperm counts, and epididymal sperm motility (29).

In the light of these findings, we designed this study to investigate the possible protective effects of resveratrol treatment on nicotine-induced oxidative damage in rat urinary system by determining biochemical and histopathological parameters of oxidant tissue and by carrying out functional experiments to evaluate smooth muscle contractility.

\section{METHODS \\ Animals}

Male Wistar albino rats (300-350 g) obtained from Marmara University, Animal House were kept in a light- and temperature-controlled room with 12:12-h light-dark cycles, where the temperature $\left(22 \pm 0.5^{\circ} \mathrm{C}\right)$ and relative humidity $(65-70 \%)$ were kept constant. The animals were fed a standard pellet. The study was approved by the Marmara University Animal Care and Use Committee.

\section{Experimental groups}

Since nicotine is a major component of cigarette smoke, rats were injected with nicotine to mimic the effects of chronic exposure to nicotine. Rats in the control and nicotine-treated groups were injected intraperitoneally (ip) with either saline or nicotine hydrogen bitartarate $(0.6 \mathrm{mg} / \mathrm{kg} /$ day; Sigma Chemical Co., St. Louis, Missouri, USA), respectively. Along with saline or nicotine injections that were continued for 28 days, either resveratrol (99\% purity; Mikrogen Pharmaceuticals, Turkey; RVT; $10 \mathrm{mg} / \mathrm{kg} /$ day) or saline was administered daily by intragastric gavage. The dose and duration of nicotine and resveratrol treatments are based on our previous studies $(6-8,28)$. Each experimental subgroup consisted of 16 rats.

On the 29th day of the treatments, rats were decapitated; trunk blood was collected and kidney, urinary bladder and corpus cavernosum tissues were excised. In half of all the experimental groups, corpus cavernosum and bladder were immediately 

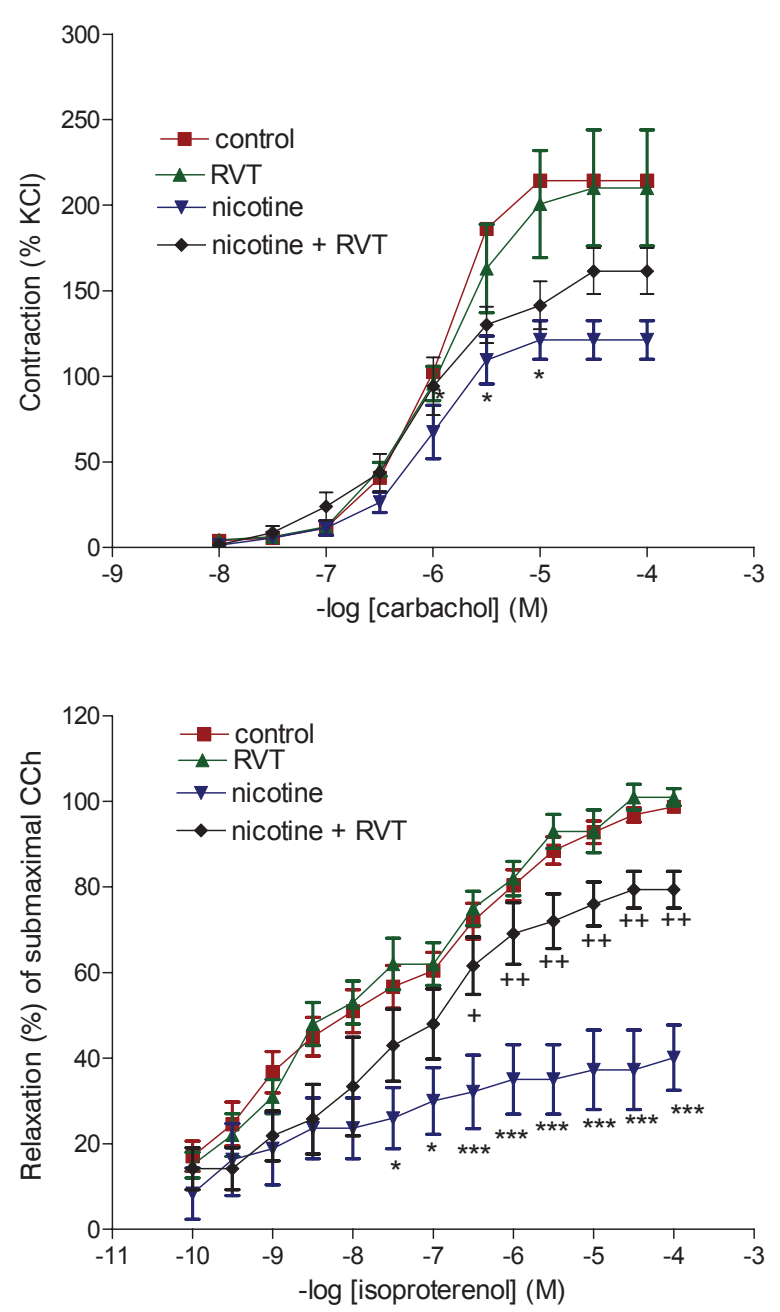

FIGURE 2. Concentration- response curve obtained by cumulative addition of a) carbachol and b) isoproterenol to bladder strips. Values are shown as mean \pm SEM of eight experiments. ${ }^{*} p<0.05$, ${ }^{* * *} p<0.001$ compared with saline-treated control group. ${ }^{+} p<0.05,{ }^{++} p<0.01$ compared with saline-treated nicotine group. Data are given as mean \pm SEM and each group consists of 8 rats.

prepared for the in vitro contractility studies. In the other half of the groups, corpus cavernosum, bladder and kidney samples were stored at $-80^{\circ} \mathrm{C}$ until the measurement of malondialdehyde (MDA), glutathione (GSH), and luminol-lucigenin chemiluminescence (CL) levels. Extra tissue samples were fixed in $10 \%$ buffered formalin solution and prepared for routine paraffin embedding for histological analysis.

\section{Blood Assays}

In blood samples, levels of blood urea nitrogen (BUN), creatinine, 8-hydroxy-2'-deoxyguanosine (8-OHdG), pro-inflammatory cytokines, as well as lactate dehydrogenase (LDH) activity and plasma total antioxidant capacity (AOC) were analyzed. Blood urea nitrogen (30), plasma creatinine (31) concentrations and LDH levels (32) were determined spectrophotometrically using an automated analyzer (Bayer Opera biochemical analyzer). Plasma levels of pro-inflammatory cytokines, tumor necrosis factor-alpha (TNF- $\alpha$ ) and interleukin-1 beta (IL-1 $\beta$ were quantified using enzyme-linked immunosorbent assay (ELISA) kits specific for the previously mentioned rat cytokines according to the manufacturer's instructions and guidelines (Biosource Europe S.A., Nivelles, Belgium). The total antioxidant capacity (AOC) in plasma was measured by using a colorimetric test system (ImAnOx, cataloge no.KC5200, Immunodiagnostic AG, D-64625 Bensheim) according to the instructions provided by the manufacturer. As an indicator of oxidative DNA damage, 8-hydroxy-2'-deoxyguanosine (8-OHdG) content in the extracted DNA solution were determined by ELISA method (Highly Sensitive 8-OHdG ELISA kit, Japan Institute for the Control of Aging, Shizuoka, Japan). These particular assay kits were selected because of their high degree of sensitivity, specificity, inter- and intraassay precision and small amount of plasma sample required conducting the assay.

\section{In vitro organ bath experiments}

In order to assess the function of the bladder and corpus cavernosum, contractile responses of these tissues were studied in in vitro conditions. The bladder dome was immediately removed and separated from the bladder base at the level of urethral orifices and longitudinal strips of the posterior of the bladder dome $(1.5 \times 5 \mathrm{~mm})$ were prepared. Corpus cavernosum excised from the penis of the rats was dissected free of the tunica albuginea and cut into $2 \times 2 \times 15 \mathrm{~mm}$ strips. Corporeal strips were bathed in Krebs-bicarbonate buffer containing 118 $\mathrm{mM} \mathrm{NaCl}, 4.7 \mathrm{mM} \mathrm{KCl}, 2.5 \mathrm{mM} \mathrm{CaCl}_{2}, 25 \mathrm{mM} \mathrm{NaHCO}_{3}, 1.2$ $\mathrm{mM} \mathrm{MgSO} 4,1.2 \mathrm{mM} \mathrm{KHPO}_{4}$ and $11.1 \mathrm{mM}$ glucose, whereas bladder strips were bathed in Tyrode's solution containing $124.9 \mathrm{mM} \mathrm{NaCl}, 2.6 \mathrm{mM} \mathrm{KCl}, 23.8 \mathrm{mM} \mathrm{NaHCO}, 0.5 \mathrm{mM}$ $\mathrm{MgCl}_{2}, 0.4 \mathrm{mM} \mathrm{NaH}{ }_{2} \mathrm{PO}_{4}, 1.8 \mathrm{mM} \mathrm{CaCl}_{2}$ and $5.5 \mathrm{mM}$ glucose. The strips were mounted in $20 \mathrm{ml}$ double-jacketed organ baths that were aerated with $95 \% \mathrm{O}_{2}$ and $5 \% \mathrm{CO}_{2}(\mathrm{pH} 7.4)$ at $37{ }^{\circ} \mathrm{C}$. The tissues were equilibrated for 40 min under a resting tension of $1 \mathrm{~g}$. Isometric contractions were recorded using a Model FT03 force displacement transducer (Grass Instruments, Quincy, Massachusetts, USA) coupled to a Model 7 polygraph (Grass Instruments). After the equilibration period, the tissues were first exposed to $\mathrm{KCl}$ for maximal contraction, then the contraction or relaxation responses were studied accordingly.

The contractile responses of the corporeal strips to $10^{-8}$ to $10^{-4}$ $\mathrm{M}$ phenylephrine were obtained cumulatively and expressed as the percentage of the maximal contraction induced by 124 $\mathrm{mM} \mathrm{KCl}$. After a 30-min washout period, corporeal tissues were contracted with a submaximal dose $\left(10^{-5} \mathrm{M}\right)$ of phenylephrine. The relaxation responses of the pre-contracted tissues were evaluated by adding increasing concentrations of $\mathrm{CCh}$ $\left(10^{-8}\right.$ to $\left.10^{-4} \mathrm{M}\right)$. Following another washout period, sodium nitroprusside was added cumulatively $\left(10^{--8}-10^{-3} \mathrm{M}\right)$ to the corpus cavernosum strips that were pre-contracted with the same submaximal dose of phenylephrine.

The contractile responses of the bladder strips to $10^{-8}$ to $10^{-4} \mathrm{M}$ carbachol (CCh) were obtained cumulatively and expressed as the percentage of the maximal contraction induced by $80 \mathrm{mM}$ $\mathrm{KCl}$. After a 30-min washout period, the bladder strips, which were precontracted with the submaximal dose of CCh $\left(3 \times 10^{-6}\right.$ $\mathrm{M})$, were relaxed by isoproterenol $\left(10^{-10}\right.$ to $\left.10^{-4} \mathrm{M}\right)$ and the relaxation responses were expressed as the percent of the contraction caused by submaximal CCh. 

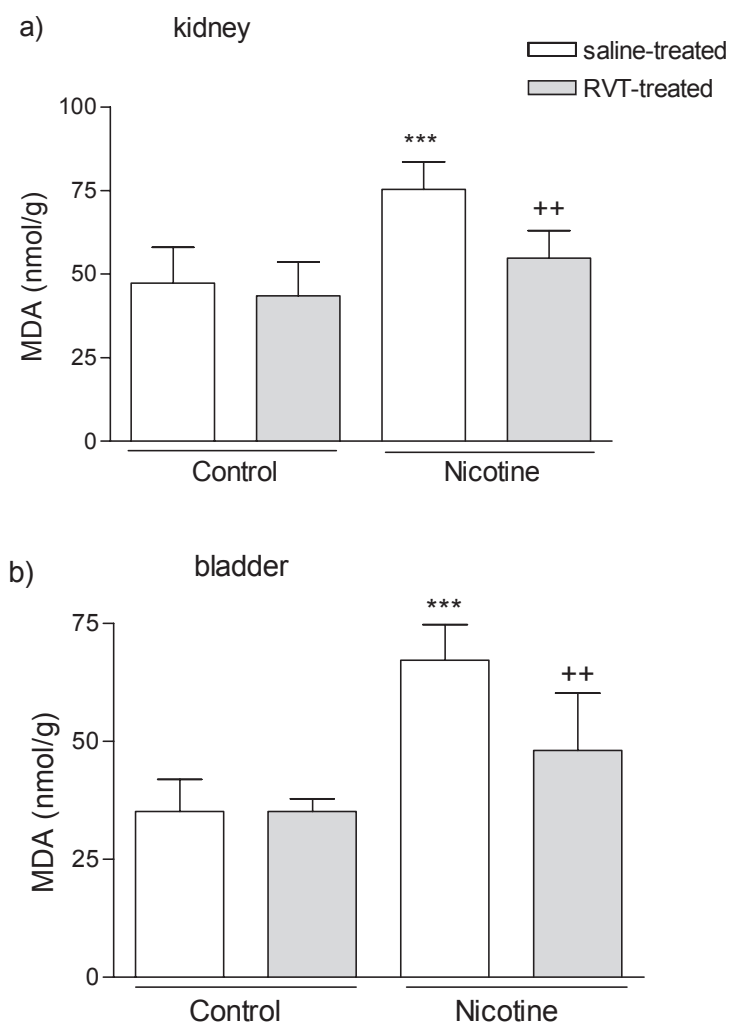

c)

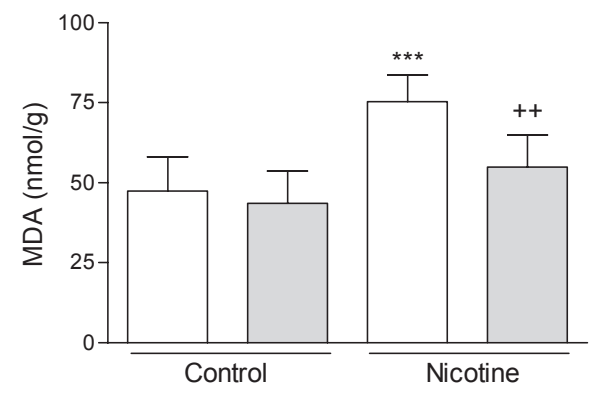

FIGURE 3. Malondialdehyde (MDA) levels in the kidney (a); bladder (b); and corpus cavernosum (c) tissues of saline or resveratrol (RVT) treated control and nicotine groups. ${ }^{* * *} p<0.001$; compared to control group; ${ }^{++} p<0.01$ compared to saline-treated nicotine group. Data are given as mean \pm SD and each group consists of 8 rats.

\section{MDA and GSH assays}

Tissue samples were homogenized with ice-cold $150 \mathrm{mM} \mathrm{KCl}$ for the determination of MDA and GSH levels. The MDA levels were assayed for products of lipid peroxidation (33) and results are expressed as nmol MDA/g tissue. GSH was determined by the spectrophotometric method, based on the use of Ellman's reagent (34) and results are expressed as $\mu \mathrm{mol} \mathrm{GSH/}$ $\mathrm{g}$ tissue.

\section{MPO activity}

MPO activity in tissues was measured in a procedure similar to that documented by Hillegas et al., (35). Tissue samples were homogenized in $50 \mathrm{mM}$ potassium phosphate buffer (PB, $\mathrm{pH}$ 6.0), and centrifuged at 41,400 g (10 min); pellets were suspended in $50 \mathrm{mM}$ PB containing $0.5 \%$ hexadecyltrimethylammonium bromide (HETAB). After three freeze and thaw cycles, with sonication between cycles, the samples were centrifuged at 41,400 $\mathrm{g}$ for $10 \mathrm{~min}$. aliquots $(0.3 \mathrm{ml})$ were added to 2.3 $\mathrm{ml}$ of reaction mixture containing $50 \mathrm{mM} \mathrm{PB}$, o-dianisidine, and $20 \mathrm{mM} \mathrm{H} \mathrm{H}_{2} \mathrm{O}_{2}$ solution. One unit of enzyme activity was defined as the amount of the MPO present that caused a change in absorbance measured at $460 \mathrm{~nm}$ for $3 \mathrm{~min}$. MPO activity was expressed as $\mathrm{U} / \mathrm{g}$ tissue.

\section{Chemiluminescence (CL) assay}

To assess the role of reactive oxygen species in nicotine-induced tissue damage, luminol and lucigenin chemiluminescences were measured as indicators of radical formation. Lucigenin (bis-Nmethylacridiniumnitrate) and luminol (5- amino-2,3-dihydro1,4-phthalazinedione) were obtained from Sigma (St Louis, MO, USA). Luminol detects a group of reactive species, i.e. ${ }^{\bullet} \mathrm{OH}$, $\mathrm{H}_{2} \mathrm{O}_{2}, \mathrm{HOCl}$ radicals, while lucigenin is selective for $\mathrm{O}_{2}^{-}$. Measurements were made at room temperature using Junior LB 9509 luminometer (EG\&G Berthold, Germany). Specimens were put into vials containing PBS-HEPES buffer (0.5 M PBS containing 20 mM HEPES, pH 7.2). Reactive oxygen species were quantitated after the addition of either lucigenin or luminol as an enhancer for a final concentration of $0.2 \mathrm{mM}$. Counts were obtained at $1 \mathrm{~min}$ intervals and the results were given as the area under curve (AUC) for a counting period of $5 \mathrm{~min}$. Counts was corrected for wet tissue weight (rlu/mg tissue) (36).

\section{Histological analysis}

Kidney, bladder and corpus cavernosum samples were prepared for routine light microscopic examination. Paraffin sections were stained with Hematoxylin \& Eosin (H\&E) and examined under an Olympus BH-2 (Tokyo, Japan) photomicroscope by an experienced histologist who was unaware of the treatment conditions.

\section{Statistics}

Statistical analysis was carried out using GraphPad Prism 3.0 (GraphPad Software, San Diego; CA; USA). All data are expressed as means \pm SEM. Groups of data were compared with an analysis of variance (ANOVA) followed by Tukey's multiple comparison tests. Values of $\mathrm{p}<0.05$ were regarded as significant.

\section{RESULTS}

Effect of resveratrol on nicotine-induced alterations in renal function and in plasma oxidant-antioxidant status

Chronic exposure to nicotine elevated plasma BUN and creatinine levels significantly $(p<0.001)$ in the orally saline-treated group as compared to control groups (Table 1). In the group where RVT was given orally along with nicotine injections, changes in BUN and creatinine were abolished $(p<0.01)$ and the values were not different than those of the control animals.

As an indicator of generalized tissue damage due to chronic nicotine administration, plasma LDH activity showed a significant increase $(p<0.001)$ and this effect was reversed signifi- 
TABLE 1. Plasma blood urea nitrogen (BUN) and creatinine levels, lactate dehydrogenase (LDH) activity, total antioxidant capacity (AOC), 8-hydroxy-2'deoxyguanosine (8-OHdG), TNF- $\alpha$ and IL-1 $\beta$ levels in the saline- (control) or nicotine-injected groups treated orally with either saline or resveratrol (RVT) For each group $n=8$

\begin{tabular}{|c|c|c|c|c|}
\hline & $\begin{array}{l}\text { Control } \\
\text { groups } \\
\text { Saline- } \\
\text { treated }\end{array}$ & $\begin{array}{c}\text { RVT- } \\
\text { treated }\end{array}$ & $\begin{array}{c}\text { Nicotine } \\
\text { groups } \\
\text { Saline-treated }\end{array}$ & RVT-treated \\
\hline BUN (U/L) & $23.0 \pm 1.5$ & $24.3 \pm 1.8$ & $32.7 \pm 1.4^{* \star \star}$ & $25.0 \pm 0.7^{++}$ \\
\hline Creatinine $(\mathrm{U} / \mathrm{L})$ & $0.45 \pm 0.04$ & $0.39 \pm 0.01$ & $0.90 \pm 0.06 * * \star$ & $0.61 \pm 0.03^{++}$ \\
\hline $\mathrm{LDH}(\mathrm{U} / \mathrm{L})$ & $1262 \pm 73$ & $1188 \pm 68$ & $2114 \pm 128^{\star \star \star}$ & $1212 \pm 47^{+++}$ \\
\hline $\mathrm{AOC}(\mathrm{pg} / \mathrm{ml})$ & $424 \pm 28.3$ & $428 \pm 32.9$ & $269 \pm 15.8^{* \star \star}$ & $423 \pm 18.3^{+++}$ \\
\hline 8-OHdG(ng/ml) & $1.42 \pm 0.2$ & $1.34 \pm 0.3$ & $6.71 \pm 0.5^{* \star \star}$ & $2.7 \pm 0.4^{+++}$ \\
\hline TNF- $\alpha(\mathrm{pg} / \mathrm{ml})$ & $3.3 \pm 0.5$ & $4.2 \pm 0.5$ & $15.7 \pm 1.3^{* \star *}$ & $7.1 \pm 0.7^{\star},+++$ \\
\hline IL-1 $\beta(p g / m l)$ & $6.0 \pm 0.5$ & $4.7 \pm 0.7$ & $18.7 \pm 2.1 * \star *$ & $10.2 \pm 0.6^{+++}$ \\
\hline
\end{tabular}

cantly by RVT treatment ( $p<0.001$; Table 1$)$. Similarly, in the plasma of saline-treated nicotine group, oxidative DNA marker $8-O H d G$ was increased $(p<0.001)$, while AOC was significantly $(p<0.001)$ depressed. On the other hand, RVT treatment reduced the plasma $8-\mathrm{OHdG}$ level significantly $(\mathrm{p}<0.001)$ and prevented the reduction in AOC $(p<0.001)$. Additionally, in the saline-treated group with chronic nicotine exposure, the plasma levels of pro-inflammatory cytokines, TNF- $\alpha$, and IL$1 \beta$, were significantly increased $(p<0.001)$ when compared to control groups, while nicotine-induced elevations in the cytokine levels were significantly abolished when nicotine treatment was accompanied by RVT administration ( $\mathrm{p}<0.001)$.

\section{Effect of resveratrol on nicotine-induced alterations in corpus cavernosum contractility}

In the corpus cavernosum strips of the control group, which were pre-contracted with $124 \mathrm{mM} \mathrm{KCl}$, cumulatively added phenylephrine $\left(10^{-8}\right.$ to $\left.10^{-4} \mathrm{M}\right)$ caused a concentration-dependent contraction with an $\mathrm{EC}_{50}$ of $3.86 \times 10^{-6} \mathrm{M}$ (Fig. 1a). In the chronically nicotine-injected group with oral saline treatment, the contractile response of corpus cavernosum to phenylephrine was decreased without causing any significant effect on $\mathrm{EC}_{50}$ $\left(\mathrm{EC}_{50}=3.90 \times 10^{-6} \mathrm{M}\right)$. However, in RVT- treated nicotine group, the contractile response of the corpus cavernosum was higher than in the saline-treated nicotine group, resulting in an $\mathrm{EC}_{50}$ of $1.42 \times 10^{-6} \mathrm{M}$. The contractile responses of the RVT- and salinetreated control groups were not different from each other.

CCh added cumulatively $\left(10^{-8}-10^{-4} \mathrm{M}\right)$ to corporeal tissues, which were pre-contracted with the submaximal dose of phenylephrine $\left(10^{-5} \mathrm{M}\right)$, caused a dose-dependent relaxation response in the control group $\left(\mathrm{ED}_{50}=1.2 \times 10^{-5} \mathrm{M}\right)(\mathrm{Fig}$. $1 \mathrm{~b})$. In the saline-treated nicotine group, relaxation response of corpus cavernosum strips to $C C h$ was markedly reduced $\left(\mathrm{ED}_{50}=4.43 \times 10^{-6}\right.$ $\mathrm{M})$ as compared to control groups. In the RVT-treated nicotine group, however, the relaxation response was higher $\left(\mathrm{ED}_{50}=6.97\right.$ $\times 10^{-6} \mathrm{M}$ ) than that of the saline-treated nicotine group. kidney

a)

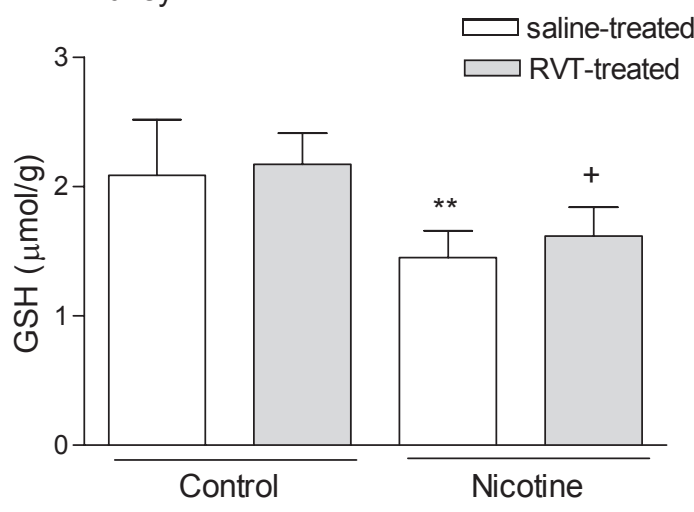

b)

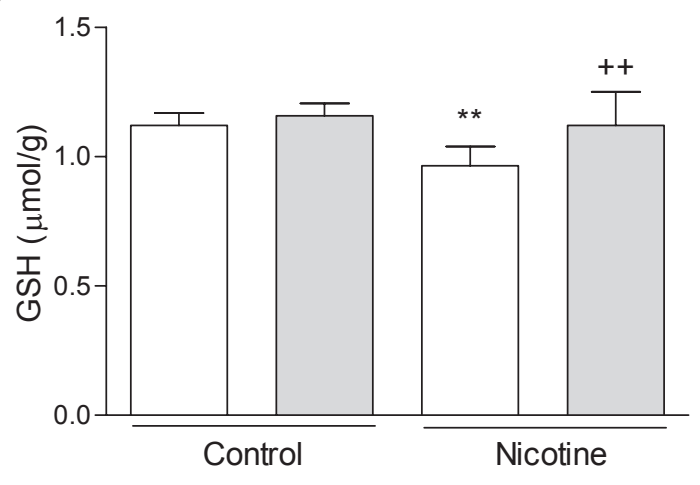

c)

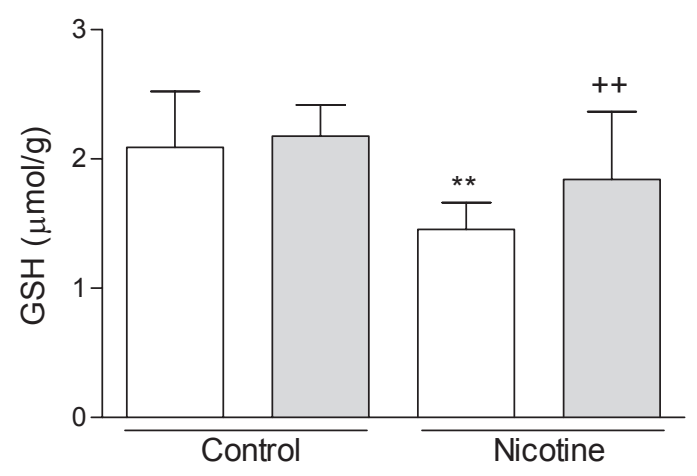

FIGURE 4. Glutathione (GSH) levels in the kidney (a); bladder (b); and corpus cavernosum (c) tissues of saline or resveratrol (RVT) treated control and nicotine groups. ${ }^{* *} p<0.01$; compared to control group; ${ }^{+} p<0.05,{ }^{++} p<0.01$ compared to saline-treated nicotine group. Data are given as mean \pm SD and each group consists of 8 rats.

Sodium nitroprusside, when added cumulatively $\left(10^{--8}-10^{-3}\right.$ M) to strips that were pre-contracted with the submaximal dose of phenylephrine, dose-dependent relaxation responses were 


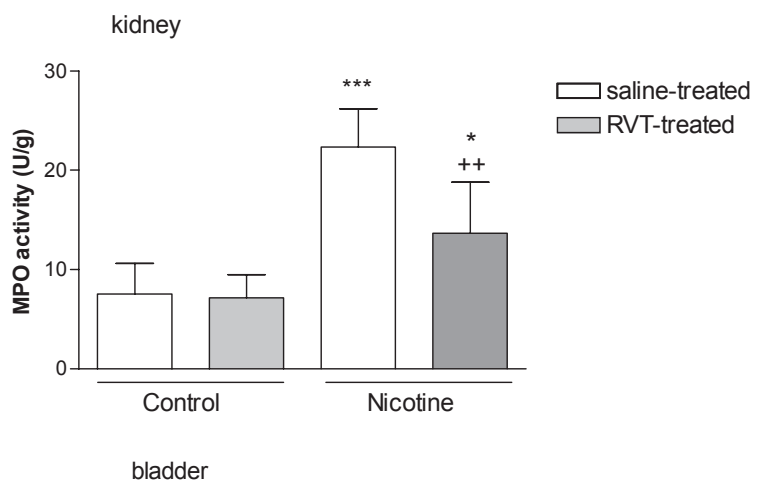

b)

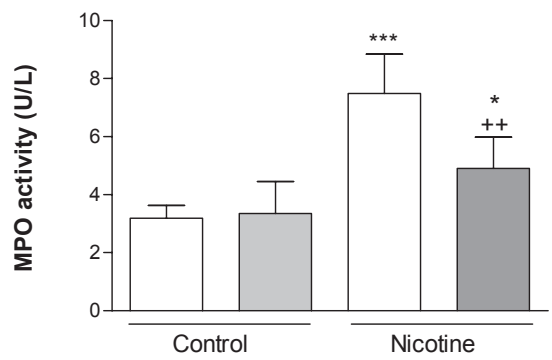

corpus cavernosum

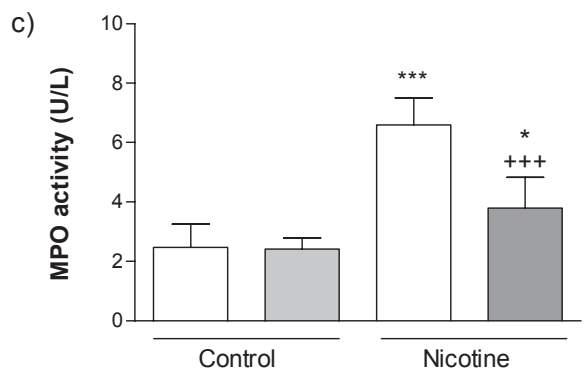

FIGURE 5. Myeloperoxidase (MPO) activity in the kidney (a); bladder (b); and corpus cavernosum (c) tissues of saline or resveratrol (RVT) treated control and nicotine groups. ${ }^{*} p<0.05,{ }^{+++} p<0.001$; compared to control group; ${ }^{++} p<0.01$, ${ }^{+++} p<0.001$ compared to saline-treated nicotine group. Data are given as mean \pm SD and each group consists of 8 rats.

obtained. Although this direct smooth muscle relaxant caused a similar relaxation response in the corporeal tissues of all groups (Fig. 1c), the relaxation response of the saline-treated nicotine group was significantly lower at certain concentrations $\left(\mathrm{ED}_{50}=\right.$ $\left.1.39 \times 10^{-5} \mathrm{M}\right)$ from that of the saline-treated control group $\left(\mathrm{ED}_{50}=7.23 \times 10^{-6} \mathrm{M}\right)$, and this effect was reversed in the nicotine group that was treated with RVT $\left(\mathrm{ED}_{50}=1.05 \times 10^{-5} \mathrm{M}\right)$.

\section{Effect of resveratrol on nicotine-induced alterations in bladder contractility}

Similar to corpus cavernosum results, cumulatively added $\mathrm{CCh}$ in the saline-treated control group caused a concentration-dependent contraction in bladder strips that were precontracted with $\mathrm{KCl}\left(\mathrm{EC}_{50}=1.03 \times 10^{-6} \mathrm{M}\right)$ (Fig. 2a). In the saline-treated nicotine group, the contraction response of the bladder strip to CCh was decreased $\left(\mathrm{EC}_{50}=8.39 \times 10^{-7} \mathrm{M}\right)$, while in the RVT-treated nicotine group, the reduction in the contractile response was relatively less $\left(\mathrm{EC}_{50}=7.80 \times 10^{-7} \mathrm{M}\right)$. The pre-contracted (with $3 \times 10^{-6} \mathrm{M} \mathrm{CCh}$ ) bladder strips were relaxed in a concentration-dependent manner by the addition of isoproterenol $\left(10^{--10}-10^{-4} \mathrm{M}\right)$. The $\mathrm{ED}_{50}$ value of saline-treated nicotine group $\left(\mathrm{ED}_{50}=2.01 \times 10^{-8} \mathrm{M}\right)$ was significantly lower than that of the control group $\left(\mathrm{ED}_{50}=8.1 \times 10^{-8} \mathrm{M}\right)$, while this decreased relaxation response was reversed in the RVT-treated nicotine group $\left(\mathrm{ED}_{50}=6.61 \times 10^{-8} \mathrm{M}\right)$. (Fig. $\left.2 \mathrm{~b}\right)$

\section{Effect of resveratrol on nicotine-induced oxidative tissue damage}

The levels of TBARS, which is a major degradation product of lipid peroxidation, were significantly increased in kidney, bladder and corpus cavernosum tissues of saline-treated nicotine group, compared with the control groups $(\mathrm{p}<0.001)$, while RVT treatment in the other nicotine group caused marked decreases in the MDA levels of all tissues ( $p<0.01$, Fig. 3). Accordingly, chronic nicotine administration caused significant decreases in the tissue GSH levels of kidney, bladder and corpus cavernosum $(\mathrm{p}<0.01)$. However, in the RVT-treated nicotine group, the depletion of GSH in all tissues was prevented $(\mathrm{p}<0.05-0.01$, Fig. 4). Also, MPO activity-an index for neutrophil infiltration was increased in chronic nicotine treatment groups. The increase was reversed by resveratrol supplementation (Fig. 5).

\section{Effect of resveratrol on nicotine-induced generation of reactive oxygen species}

Luminol and lucigenin chemiluminescences in kidney, bladder and corpus cavernosum tissues of the saline-treated nicotine group were significantly $(p<0.05$ and $p<0.001)$ higher than those of the controls indicating enhanced generation of reactive oxygen species in these tissues. On the other hand, luminol and lucigenin chemiluminescence in these tissues were significantly $(\mathrm{p}<0.05-0.01)$ suppressed in the other nicotine group that was treated with RVT (Fig. 6).

\section{Histological findings}

The light microscopic evaluation of the kidneys in the salinetreated nicotine group showed extensive degeneration with severe vasocongestion in the parenchyma, wide dilatations around the glomeruli, and vacuolizations and debris in the tubules, while a regular morphology of the renal parenchyma with well-designated glomeruli and tubuli were observed in both control groups (Fig. 7a). In the kidneys of the animals treated with nicotine and resveratrol, vasocongestion in the parenchyma was no longer present and the glomeruli maintained a better morphology with a mild degeneration confined to the proximal tubuli (Fig. $7 \mathrm{~b}$ and $7 \mathrm{c}$ ).

Histopathological evaluation of the urinary bladders in the control group revealed a regular mucosal layer with an overlying mucus coat, whereas an extensive surface urothelial cell detachment with a nude lamina propria and interstitial edema of the connective tissue layer was observed in the bladders of the saline-treated nicotine group (Fig. 8a, 8b). In the RVT-treated nicotine group, the urothelium appeared to gain its integrity but a mild interstitial edema was still present (Fig. 8c).

As compared to the regular morphology of corpus cavernosum present in the control group (Fig. 9a), chronic nicotine exposure accompanied with saline treatment led to moderate 

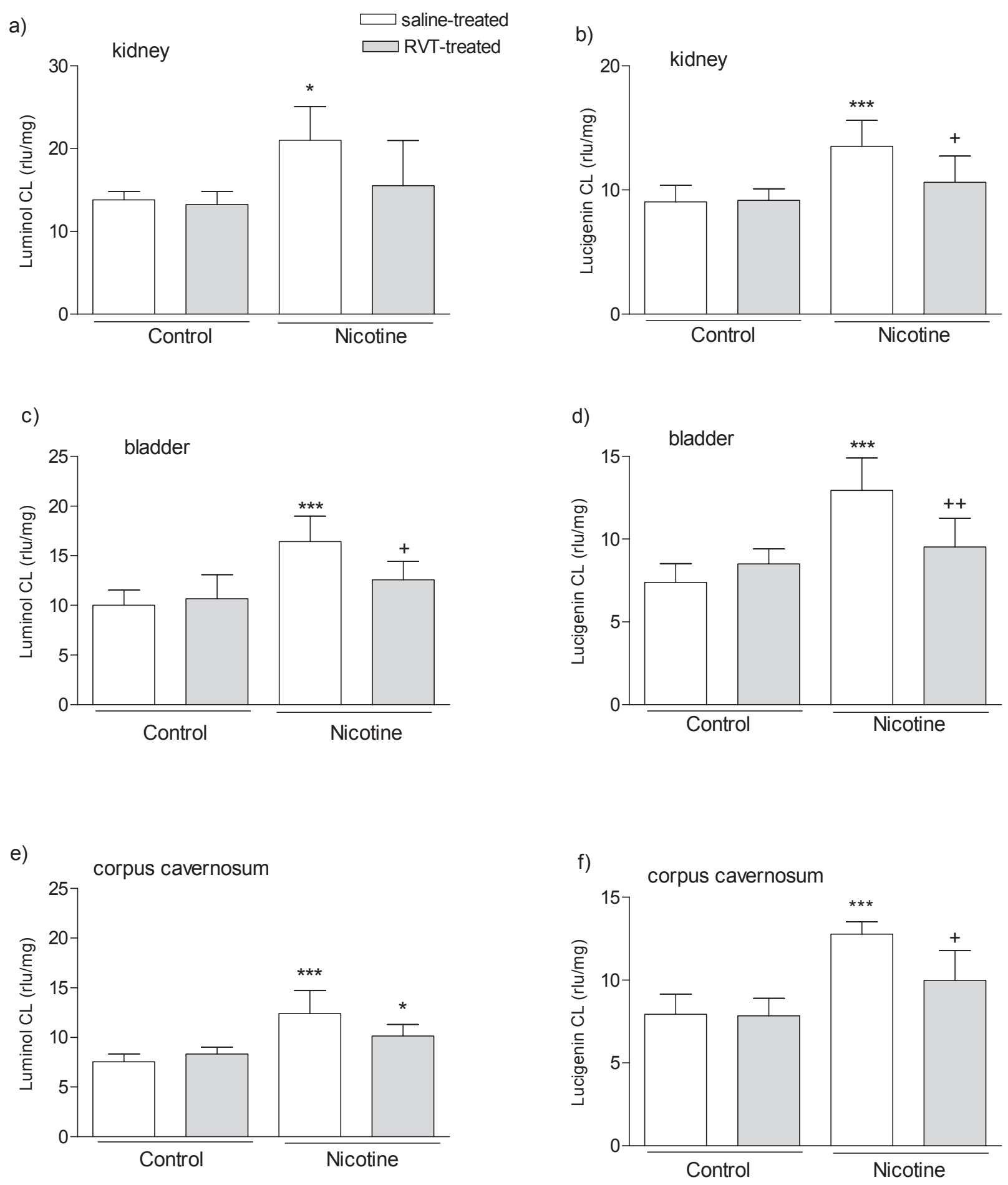

FIGURE 6. Luminol and lucigenin chemiluminescence (CL) levels in the kidney (a and b); bladder (c and d); and corpus cavernosum (e and f) tissues of saline or resveratrol (RVT) treated control and nicotine groups. ${ }^{*} p<0.05$, ${ }^{* * *} p<0.001$; compared to control group; ${ }^{+} p<0.05,{ }^{++} p<0.01$ compared to saline-treated nicotine group. Data are given as mean \pm SD and each group consists of 8 rats.

degenerations specifically in the capillaries of corpus cavernosum (Fig. 9b). Constriction of capillaries with cork-screw shaped nuclei was observed in many areas, while congestion of blood vessels was another feature noticed in the tissues. In the nicotine group that was also treated with resveratrol, the congestion of the blood vessels was reduced and the nuclei of 

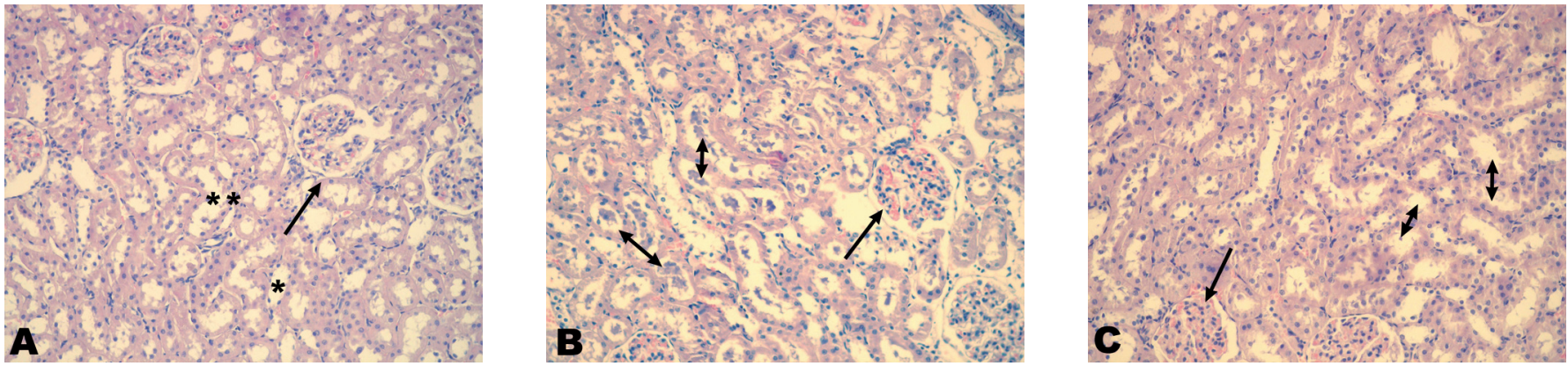

FIGURE 7. Photomicrographs of kidney revealed regular structue of glomeruli (arrow) and tubuli (*) in the saline-treated control group (a), severe vascular congestion in the interstitium (arrow) and degenerated glomeruli and tubuli (double-headed arrows) in the saline-treated nicotine group (b), and a better morphology in the glomeruli (arrow) and tubuli (double-headed arrows ) with mild interstitial congestion in the resveratrol-treated nicotine group (c). HE stain, Original magnification X 200.

the endothelium showed a nearly regular appearance (Fig. 9c).

\section{DISCUSSION}

The results of the present study demonstrate that nicotine-induced oxidative damage in the kidney, urinary bladder and corpus cavernosum was ameliorated by resveratrol treatment, as evidenced by alterations in luminol and lucigenin CL, GSH, $\mathrm{MPO}$ and MDA levels. In addition, impairment in renal function due to chronic nicotine administration that was assessed by elevated BUN and creatinine levels in plasma, as well as contractile dysfunction and morphological changes in the oxidatively injured tissues were also improved by resveratrol treatment. Moreover, the increased plasma levels of the proinflammatory cytokines, LDH and 8-OHdG were also reversed when resveratrol treatment has accompanied the chronic administration of nicotine.

Epidemiologic studies suggest that cigarette smoke worsens the progression of renal injury in patients with glomerular diseases and accelerates the progression of renal failure in patients with diabetic and non-diabetic renal disease (23). Either in vivo or in vitro treatment with nicotine has resulted in glomerular injury via the activation of inflammatory mediators, explaining the mechanisms involved in the deleterious effects of cigarette smoking on renal disease (37). A number of clinical and animal studies show that cigarette smoke produces generalized endothelial dysfunction in virtually every vascular bed (38-40), which is usually an indicator of an increased oxidative stress due to release of reactive oxygen species (ROS). It was recently demonstrated that cigarette smoke-induced endothelial oxidative stress results in nuclear factor kappa-B (NF-kB) activation and, consequently, pro-inflammatory alterations in vascular phenotype (41). Nicotine, a major toxic component of cigarette smoke (42), is chemotactic for polymorphonuclear (PMN) leukocytes and enhances the responsiveness of PMN leukocytes to activated complement C5a, thus generating ROS (43). Moreover, nicotine has been known to result in oxidative stress by inducing the generation of ROS in the tissues. In the present study, marked elevation of luminol and lucigenin chemiluminescence levels in the kidney, bladder and corpus cavernosum of saline-treated nicotine group indicates the enhanced generation of $\mathrm{H}_{2} \mathrm{O}_{2}, \mathrm{OH}^{-}$, hypochlorite, peroxynitrite, lipid peroxyl radicals and superoxide radicals. These ROS, in turn, are capable of initiating and promoting oxidative damage in the form of lipid peroxidation (44). In accordance with CL increase, TBARS levels in all the studied tissues were also increased significantly implicating the presence of enhanced lipid peroxidation, which is an autocatalytic mechanism leading to oxidative destruction of cellular membranes (45). Since membrane lipids are vital for the maintenance and integrity of cell function, the breakdown of membrane phospholipids by lipid peroxidation is expected to cause cellular injury by inactivation of membrane enzymes and receptors, depolymerisation of polysaccharides, as well as protein cross-linking and fragmentation (46), all of which play an important role in the pathogenesis of organ failures that may participate in the pathogenesis of several diseases. Secondary lipid peroxidation
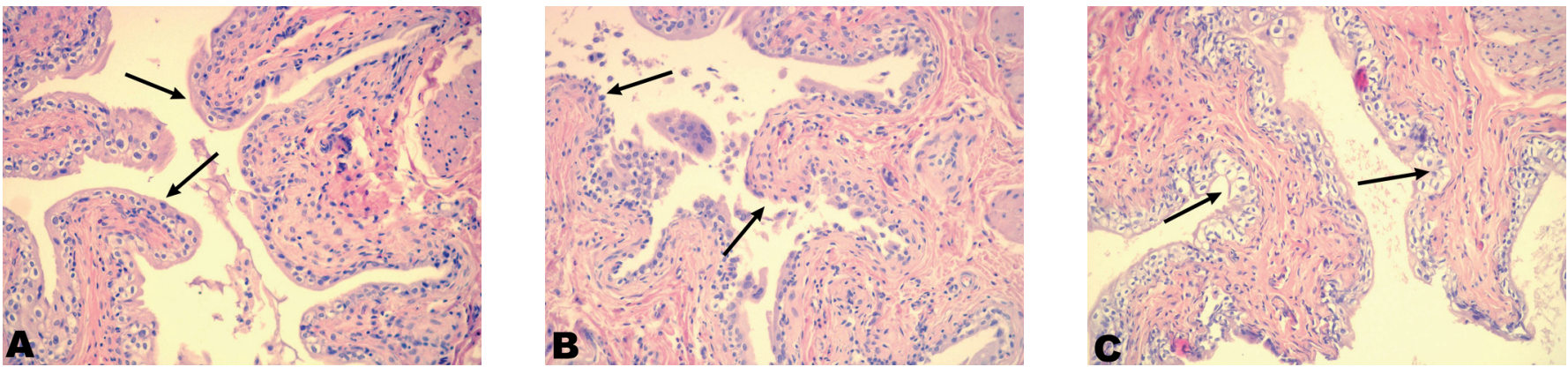

FIGURE 8. Photomicrographs of bladder revealed regular structure of the urothelial mucosa (arrows) in the saline-treated control group (a), extensive detachment of surface urothelial cells (arrows) vasocongestion in the lamina propria in the saline-treated nicotine group (b), and reversal of degenerated epithelium with regular contours (arrows) in the resveratrol-treated nicotine group, note the persistent vasocongestion and interstitial edema (c). HE stain, Original magnification $\mathrm{X} 200$ 

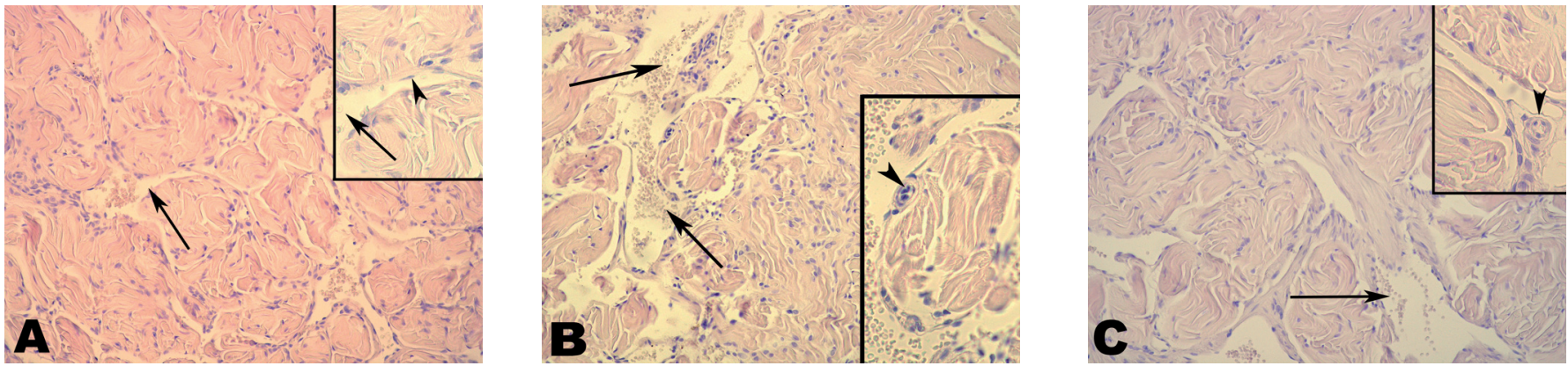

FIGURE 9. Photomicrographs of corpus cavernosum revealed a regular appearance of cavernous tissue with non-congestive vascular areas (arrows), nucleus of endothelium (inset, arrowhead) in the saline-treated control group (a); moderate degree of congestion in vascular areas (arrows) with cork-screw shaped nucleus (inset, arrowhead) in the saline-treated nicotine group (b); reduced congestion of vascular areas (arrow) and nearly-regular shape of nuclei (inset, arrowhead) in the resveratroltreated nicotine group (c). HE stain, original magnification X200, insets X400.

products such as MDA may exert similar toxic effects, which can prolong and potentiate the primary free radical-initiated damage $(47,48)$. In agreement with these observations, the findings of the current study demonstrate that chronic nicotine treatment impairs the renal functions as well as bladder and corpus cavernosum contractility and these altered functions are accompanied by elevated lipid peroxidation in the related tissues.

Since it has been demonstrated that oxidative stress takes a part in the pathogenesis of nicotine-induced impairments in various organ functions, including the urogenital system (5-8, 49), free radical ablation with the antioxidant agents seems to be beneficial for preventing the oxidant-induced tissue damage. In our previous studies, we have shown that melatonin and taurine protected renal and urinary bladder tissues against nicotine-induced oxidative damage through their antioxidant effects $(8,49)$. Csiszar et al. have previously demonstrated that resveratrol treatment abrogated smoking-induced upregulation of inflammatory markers and protected aortic endothelial cells against cigarette smoking-induced apoptotic cell death (41). Similarly, in the present study, resveratrol as a powerful antioxidant inhibited plasma pro-inflammatory cytokine and tissue MDA levels, suppressed the generation of oxygen-derived radicals and improved the functions of the kidney, bladder and corpus cavernosum, implicating that tissue integrity is maintained by inhibiting the breakdown of membrane phospholipids by lipid peroxidation.

It is well known that increased generation of oxygen-derived radicals may cause a significant amount of single-strand DNA breaks which activate the nuclear poly (ADP-ribose) polymerase (PARP), a chromatin bound enzyme involved in the repair of DNA breaks (50). However, activation of the nuclear PARP accelerates NAD+ catabolism, and depletion of NAD+ compromises the mitochondrial energy metabolism, which contributes to tissue damage (51). In the current study, chronic nicotine administration caused a significant increase in plasma 8-OHdG levels, one of the most common adducts formed by oxidative DNA damage (52). However, when the rats were treated with resveratrol, plasma $8-\mathrm{OHdG}$ was reduced, indicating that resveratrol alleviated nicotine-induced toxicity in the studied tissues through a mechanism that involves the protection against oxidative DNA damage and associated changes in mitochondrial energy metabolism.
The relationship between the amount of oxidative metabolism products and the quantity of natural free radical scavengers determines the outcome of tissue damage. Several reports have indicated that nicotine-induced toxicity is coupled with GSH depletion, which is one of the essential compounds for maintaining cellular integrity $(5,53)$. In the present study, chronic nicotine administration significantly depleted GSH stores in all the studied tissues, indicating that GSH was used as an antioxidant for the detoxification of toxic oxygen metabolites, enhancing the susceptibility of the genitourinary tissues to oxidative injury. On the other hand, resveratrol reduced nicotine-induced oxidative injury with a concomitant maintenance of GSH stores in these tissues, implicating its antioxidant action in improving the tissue functions.

The effects of smoking on the vascular endothelium and peripheral nerves have been considered to play a role in chronic smoking-induced erectile dysfunction (54). Furthermore, long-term smoking causes ultrastructural damage to the corporal tissue and increases vascular stiffness. Nicotine in the cigarette smoke is an important cause of erectile dysfunction by adversely affecting intrapenile blood flow and vascular structure (55). Cotinine, the metabolite of nicotine with a long half-life, may be responsible for the prolonged effects of nicotine on the vasculature (56). Moreover, nicotine was shown to impair endothelium-mediated relaxation of penile trabecular smooth muscle (57). In the present study, chronic administration of nicotine resulted in oxidative injury of the corpus cavernosum, while its responsiveness to relaxant or constrictor agents was reduced, suggesting that nicotine-induced impaired smooth muscle function is associated with the oxidative damage of the corporeal tissue. However, addition of resveratrol improved the smooth muscle function and alleviated the oxidative damage of the corpus cavernosum. It has been proposed that resveratrol, an important constituent of Mediterranean diets, is involved in vasculoprotection and it is thought to have diverse antiatherogenic activities (58-60), such as the inhibition of LDL oxidation (61) and platelet aggregation (62) and regulation of vascular smooth muscle proliferation $(63,64)$. Recently, Ungvari et al. demonstrated that resveratrol increases the resistance to vascular oxidative stress by scavenging $\mathrm{H}_{2} \mathrm{O}_{2}$ and preventing oxidative stress-induced endothelial cell death (65). Similarly, resveratrol was shown to exert vasoprotective effects on the endothelial cells of rats exposed to cigarette smoke by inhibiting smoking- 
induced upregulation of inflammatory markers (ICAM-1, inducible nitric oxide synthase, IL-6, and TNF- $\alpha$ ), NF-KB activation and inflammatory gene expression (41). In the present study, data demonstrate that resveratrol protects against cellular oxidative stress, which is a critical step in nicotine-mediated tissue injury, and improves muscle contractility in the corpus cavernosum by scavenging free radicals and by inhibiting the generation of pro-inflammatory mediators.

In parallel with the corpus cavernosum findings, current study also provides evidence that chronic exposure to nicotine reduces the contraction and relaxation responses of the bladder smooth muscle and results in nicotine-induced oxidative injury of the tissue. It has been proposed that bladder dysfunction due to oxidant-induced tissue damage is characterized by bladder instability and impairment in detrusor contractility. Although the precise mechanisms of impaired contractile function have not been clarified, it is known that the oxidants alter contractile responses of tissues to various agents $(66,67)$ through the impairment of signal transduction systems $(68,69)$ and antioxidants such as resveratrol may restore function (70). In the current study, the significant reductions in the maximum responses may be attributed to an impairment of musca- rinic receptor-mediated signal transduction via the activity of oxidant species. It is also possible that nicotine causes contractile dysfunction directly by damaging the contractile machinery or calcium homeostasis in smooth muscle fibers of the bladder. On the other hand, treatment with resveratrol restored bladder smooth muscle contractility, further suggesting that bladder dysfunction is associated with nicotine-induced oxidative stress, and that resveratrol restored the contractile activity of urinary bladder by alleviating oxidative injury.

In conclusion, nicotine-induced dysfunction of the kidney, as well as the impaired contractile activity of urinary bladder and corpus cavernosum were restored by resveratrol, implicating that resveratrol may provide an important contribution in the prevention of nicotine-induced oxidative damage. On the basis of these data, further investigation regarding the effects of resveratrol supplementation in experimental and clinical studies is needed to confirm whether it may be beneficial in the urogenital organ dysfunction.

Acknowlegement: We would like to honor the memory of Dr. Nursal Gedik. Without her contribution, the current study would not be possible.

\section{Sıçanlarda kronik nikotin uygulamasının neden olduğu ürogenital sistemdeki fonksiyon bozuk- luğu ve oksidan hasara karşı resveratrolün koruyucu etkileri}

ÖZET: Bu çalışmada nikotinin ürogenital sistem üzerinde oluşturduğu oksidan hasara karşı resveratrolün koruyucu etkileri biyokimyasal, histolojik ve fonksiyonel olarak araştırılması amaçlanmıştır. Wistar Albino sıçanlara 28 gün boyunca $0.6 \mathrm{mg} / \mathbf{k g}$ dozunda nikotin hidrojen bitartarat veya serum fizyolojik intraperitoneal olarak enjekte edildi. Bu hayvanlara aynı zamanda resveratrol $(10 \mathrm{mg} / \mathrm{kg})$ oral yolla uygulandı. Dekapitasyon sonrası mesane, korpus kavernoz ve böbrek dokuları çıkarıldı. Kavernoz ve mesane dokularında in vitro kontraktilite çalışmaları yapılırken böbrek dokusu da dahil her üç dokudan alınan örnekler malondialdehit (MDA), glutatyon, luminol ve lusigenin kemilüminesans (KL) düzeyleri ölçümleri için $-80^{\circ} \mathrm{C}$ 'de saklandı. Dokular histolojik olarak da incelendi. Kronik nikotin uygulamasının böbrek, mesane ve korpus kavernozum dokusunda GSH düzeylerinde neden olduğu anlamlı azalma, MDA, luminol-lusigenin KL düzeylerinde neden olduğu anlamlı artışlar histolojik olarak da belirlenen oksidatif hasarı gösterdi. Nikotin uygulamasının neden olduğu serumda kan üre azotu, kreatinin, proinflamatuar sitokinler (TNF- $\alpha$ ve IL-1 $\beta$ ), laktat dehidrojenaz aktivitesi, oksidatif DNA hasarı (8-OHdG) artışları ve antioksidan kapasitedeki azalma resveratrol tedavisi ile geri çevrildi. Ayrıca kronik nikotin uygulamasının mesane ve korpus kavernozumda neden olduğu kasılma ve gevşeme yanıtlarındaki değişiklikler yine resveratrol tedavisi ile düzeldi. Resveratrol tedavisi tüm dokularda endojen GSH düzeylerini iyileştrerek oksidan hasar parametrelerini azalttı. Bu sonuçlar resveratrolün muhtemelen antioksidan etkisi ile kronik nikotinin böbrek, mesane ve korpus kavernoz dokularındaki zararlı etkilerini karşı koruyucu olduğunu göstermektedir.

ANAHTAR KELIMELER: resveratrol; nikotin; böbrek; mesane; korpus kavernozum; oksidan hasar

\section{REFERENCES}

1. Ezzati M, Lopez AD. Measuring the accumulated hazards of smoking: global and regional estimates for 2000. Tob Control, 12: 79-85, 2003

2. Ejaz S, Lim CW. Toxicological overview of cigarette smoking on angiogenesis. Environ Toxicol Pharmacol, 20: 335, 2005.

3. Qiao D, Seidler FJ, Slotkin TA. Oxidative mechanisms contributing to the developmental neurotoxicity of nicotine and chlorpyrifos. Toxicol Appl Pharmacol, 206: 1726, 2005.
4. Ashakumary L, Vijayammal PL. Additive effect of alcohol and nicotine on LPO and antioxidant defence mechanism in rats. J Appl Toxicol, 16: 305-308,1996.

5. El-Sokkary GH, Cuzzocrea S, Reiter RJ. Effect of chronic nicotine administration on the rat lung and liver: beneficial role of melatonin. Toxicology, 239: 60-67, 2007.

6. Sener G, Sehirli AO, Ipçi Y, Cetinel S, Cikler E, Gedik N. Chronic nicotine toxicity is prevented by aqueous garlic extract. Plant Foods Hum Nutr, 60: 77-86, 2005.

7. Sener G, Sehirli O, Ipçi Y, Cetinel S, Cikler E, Gedik N, Alican I. Protective effects of taurine against nicotine-in- 
duced oxidative damage of rat urinary bladder and kidney. Pharmacology, 74: 37-44, 2005.

8. Sener G, Toklu HZ, Cetinel S. $\beta$-Glucan protects against chronic nicotine-induced oxidative damage in rat kidney and bladder. Environ Toxicol Pharmacol, 23: 25-32, 2007.

9. Soleas GJ, Diamandis EP, Goldberg DM. The world of resveratrol. Adv Exp Med Biol, 492:159-182, 2001.

10. Holme AL, Pervaiz S. Resveratrol in cell fate decisions. J Bioenerg Biomembr, 39: 59-63, 2007.

11. Pirola L, Fröjdö S. Resveratrol: one molecule, many targets. IUBMB Life, 60: 323-332, 2008.

12. Seifried HE, Anderson DE, Fisher EI, Milner JA. A review of the interaction among dietary antioxidants and reactive oxygen species. J Nutr Biochem, 18: 567-579, 2007.

13. Giovannini $C$, Filesi $C$, D'Archivio M, Scazzocchio B, Santangelo C, Masella R. Polyphenols and endogenous antioxidant defences: effects on glutathione and glutathione related enzymes. Ann Ist Super Sanita, 42: 336-347, 2006.

14. Fremont L. Biological effects of resveratrol. Life Sci, 66 : 663-673, 2000.

15. Aggarwal BB, Bhardwaj A, Aggarwal RS, Seeram NP, Shishoda S, Takada Y. Role of resveratrol in prevention and therapy of cancer: preclinical and clinical studies. Anticancer Res, 24: 2783-2840, 2004.

16. Wallerath $T$, Deckert $G$, Ternes $T$, Anderson $H, L i H$, Witte K, Forstermann U. Resveratrol, a polyphenolic phytoalexin present in red wine, enhances expression and activity of endothelial nitric oxide synthase. Circulation, 106: 1652-1658, 2002.

17. $\mathrm{Wu} J M$, Wang $Z R$, Hsich TC, Bruder JL, Zou JG, Huang YZ. Mechanism of cardioprotection by resveratrol, a phenolic antioxidant present in red wine. Int J Mol Med, 8: 3-17, 2001.

18. Weisberg E. Smoking and reproductive health. Clin Reprod Fertil, 3:175-186,1985.

19. Tostes RC, Carneiro FS, Lee AJ, Giachini FR, Leite R, Osawa Y, Webb RC. Cigarette smoking and erectile dysfunction: focus on NO bioavailability and ROS generation. J Sex Med, 5: 1284-1295, 2008.

20. Valko M, Leibfritz D, Moncol J, Cronin MT, Mazur M, Telser J. Free radicals and antioxidants in normal physiological functions and human disease. Int J Biochem Cell Biol, 39: 44-84, 2007.

21. Thomas SR, Witting PK. Drummond GR. Redox control of endothelial function and dysfunction: molecular mechanisms and therapeutic opportunities. Antioxid Redox Signal, 10: 1713-1765, 2008.

22. Cooper RG. Effect of tobacco smoking on renal function Indian J Med Res, 124: 261-326, 2006.

23. Orth SR, Viedt C, Ritz E. Adverse effects of smoking in the renal patient. Tohoku J Exp Med, 194: 1-15, 2001.

24. Sebai H, Ben-Attia M, Sani M, Aouani E, GhanemBoughanmi N. Protective effect of resveratrol on acute endotoxemia-induced nephrotoxicity in rat through nitric oxide independent mechanism. Free Radic Res, 42: 913-920, 2008.

25. Eybl V, Kotyzová,D, Cerná $P$, Koutensky J. Effect of melatonin, curcumin, quercetin, and resveratrol on acute ferric nitrilotriacetate (Fe-NTA)-induced renal oxidative damage in rats. Hum Exp Toxicol, 27: 347-353, 2008.
26. Do Amaral CL, Francescato HD, Coimbra TM, Costa RS, Darin JD, Antunes LM, Bianchi Mde L. Resveratrol attenuates cisplatin-induced nephrotoxicity in rats. Arch Toxicol, 82: 363-370, 2008.

27. de Jesus Soares $T$, Volpini RA, Francescato HD, Costa RS, da Silva CG, Coimbra TM. Effects of resveratrol on glycerol-induced renal injury. Life Sci, 81:647-656, 2007.

28. Sehirli $O$, Tozan A, Omurtag GZ, Cetinel S, Contuk G, Gedik N, Sener G. Protective effect of resveratrol against naphthalene-induced oxidative stress in mice. Ecotoxicol Environ Saf, 71: 301-308, 2008.

29. Shin $S$, Jeon JH, Park D, Jang MJ, Choi JH, Choi BH, Joo SS, Nahm SS, Kim JC, Kim YB. trans-Resveratrol relaxes the corpus cavernosum ex vivo and enhances testosterone levels and sperm quality in vivo. Arch Pharm Res, 31: 83-87, 2008.

30. Talke H, Schubert GE. Enzymatic urea determination in the blood and serum in the Warburg optical test. Klin Wochenschr, 43: 174-175, 1965.

31. Slot C. The Significance Of The Systemic Arteriovenous Difference In Creatinine Clearance Determinations. Scand J Clin Lab Invest, 17: 201-208, 1965.

32. Martinek RG. A rapid ultraviolet spectrophotometric lactic dehydrogenase assay. Clin Chim Acta, 40: 91-99, 1972.

33. Beuge JA. Aust SD. Microsomal lipid peroxidation. Methods Enzymol, 53: 302, 1978.

34. Beutler E. Glutathione in red blood cell metabolism. A manual of biochemical methods. New York: Grune\&Stratton, 1975; 112.

35. Hillegass LM, Griswold DE, Brickson B, AlbrightsonWinslow C. Assessment of myeloperoxidase activity in whole rat kidney. J Pharmacol Methods, 24: 285-295, 1990.

36. Haklar G, Yuksel M, Yalcin AS. Chemiluminescence in the measurement of free radicals: theory and application on a tissue injury model. Marmara Med J, 11: 56-60, 1998.

37. Jaimes EA, Tian RX, Joshi MS, Raij L. Nicotine Augments Glomerular Injury in a Rat Model of Acute Nephritis. Am J Nephrol, 29: 319-326, 2008.

38. Adams MR, Jessup W, Celermajer DS. Cigarette smoking is associated with increased human monocyte adhesion to endothelial cells: reversibility with oral l-arginine but not vitamin C. J Am Coll Cardiol, 29: 491-497, 1997.

39. Celermajer DS, Sorensen KE, Georgakopoulos D, Bull C, Thomas O, Robinson J, Deanfield JE. Cigarette smoking is associated with dose-related and potentially reversible impairment of endothelium-dependent dilation in healthy young adults. Circulation, 88: 2149-2155, 1993.

40. Raij L, De Master EG, Jaimes EA. Cigarette smoke-induced endothelium dysfunction: role of superoxide anion. J Hypertens, 19: 891-897, 2001.

41. Csiszar A, Labinskyy N, Podlutsky A, Kaminski PM, Wolin MS, Zhang C. Mukhopadhyay P, Pacher P, Hu F, de Cabo R, Ballabh P, Ungvari Z. Vasoprotective effects of resveratrol and SIRT1: attenuation of cigarette smokeinduced oxidative stress and proinflammatory phenotypic alterations. Am J Physiol Heart Circ Physiol, 294: H2721-2735, 2008.

42. Hoffmann D, Rivenson A, Hecht SS. The biological sig- 
nificance of tobacco-specific N-nitrosamines: smoking and adenocarcinoma of the lung. Crit Rev Toxicol, 26: 199-211, 1996.

43. Karla J, Chaudhary AK, Prasad K. Increased production of oxygen free radicals in cigarette smokers. Int J Exp Pathol, 72: 1-7, 1991.

44. Kovacic $P$, Cooksy A. Iminium metabolism for nicotine toxicity and addiction: oxidative stress and electron transfer. Med Hypotheses, 64: 104-111, 2005.

45. Stark G. Functional consequences of oxidative membrane damage. J Membr Biol, 205: 1-16, 2005.

46. Luqman S, Rizvi SI. Protection of lipid peroxidation and carbonylformation in proteins by capsaicin in human erythrocytes subjected to oxidative stress. Phytother Res, 20: 303-6, 2006.

47. Helen A, Krishnakumar K, Vijayammal PL, Augusti KT. Antioxidant effect of onion oil (Allium cepa. Linn) on the damages induced by nicotine in rats as compared to alpha-tocopherol. Toxicol Lett, 116: 61-68, 2000.

48. Kaplana C, Menon VP. Modulatory effects of curcumin on lipid peroxidation and antioxidant status during nicotine-induced toxicity. Pol J Pharmacol, 56: 581-586, 2004.

49. Sener G, Kapucu C, Paskaloglu K, Ayanoglu-Dülger G, Arbak S, Ersoy Y, Alican I. Melatonin reverses urinary system and aorta damage in the rat due to chronic nicotine administration. J Pharm Pharmacol, 56: 359-366, 2004.

50. Radons J, Heller B, Bürkle A, Hartmann B, Rodriguez ML, Kröncke KD, Burkart V, Kolb H. Nitric oxide toxicity in islet cells involves poly(ADP-ribose) polymerase activation and concomitant NAD+ depletion. Biochem Biophys Res Commun, 199: 1270-1277, 1994.

51. Evgenov OV, Liaudet L. Role of nitrosative stress and activation of poly(ADP-ribose) polymerase- 1 in cardiovascular failure associated with septic and hemorrhagic shock. Curr Vasc Pharmacol, 3: 293-299, 2005.

52. Dizdaroglu M. Oxidative damage to DNA in mammalian chromatin. Mutat Res, 275: 331-342, 1992.

53. Husain $K$, Scott BR, Reddy SK, Somani SM. Chronic ethanol and nicotine interaction on rat tissue antioxidant defense system. Alcohol, 25: 89-97, 2001.

54. Tostes RC, Carneiro FS, Lee AJ, Giachini FR, Leite R, Osawa Y, Webb RC. Cigarette smoking and erectile dysfunction: focus on NO bioavailability and ROS generation. J Sex Med, 5: 1284-1295, 2008.

55. Jeremy JY, Mikhailidis DP. Cigarette smoking and erectile dysfunction. J R Soc Health, 118: 151-155, 1998.

56. Sastry BV, Chance MB, Singh G, Horn JL, Janson VE. Distribution and retention of nicotine and its metabolite, cotinine, in the rat as a function of time. Pharmacology, 50: 128-136, 1995.

57. Mikhailidisi DP, Ganotakis ES, Papadakis JA, Jeremy JY. Smoking and urological disease. J R Soc Health, 118: 210212, 1998.

58. Ou HC, Chou FP, Sheen HM, Lin TM, Yang CH, Huey-
Herng Sheu W. Resveratrol, a polyphenolic compound in red wine, protects against oxidized LDL-induced cytotoxicity in endothelial cells. Clin Chim Acta, 364: 196204, 2006.

59. Wang Z, Zou J, Cao K, Hsieh TC, Huang Y, Wu JM. Dealcoholized red wine containing known amounts of resveratrol suppresses atherosclerosis in hypercholesterolemic rabbits without affecting plasma lipid levels. Int J Mol Med, 16: 533-540, 2005.

60. Zou J, Huang Y, Cao K, Yang G, Yin H, Len J, Hsieh TC, Wu JM. Effect of resveratrol on intimal hyperplasia after endothelial denudation in an experimental rabbit model. Life Sci, 68: 153-163, 2000.

61. Frankel EN, Waterhouse AL, Kinsella JE. Inhibition of human LDL oxidation by resveratrol. Lancet, 341: 1103 1104, 1993.

62. Stef $G$, Csiszar A, Lerea $K$, Ungvari Z, Veress G. Resveratrol inhibits aggregation of platelets from high-risk cardiac patients with aspirin resistance. J Cardiovasc Pharmacol, 48: 1-5, 2006.

63. Haider UG, Sorescu D, Griendling KK, Vollmar AM, Dirsch VM. Resveratrol suppresses angiotensin II-induced Akt/protein kinase B and p70 S6 kinase phosphorylation and subsequent hypertrophy in rat aortic smooth muscle cells. Mol Pharmacol, 62: 772-777, 2002.

64. Wang Z, Chen $Y$, Labinskyy N, Hsieh TC, Ungvari Z, $\mathrm{Wu}$ JM. Regulation of proliferation and gene expression in cultured human aortic smooth muscle cells by resveratrol and standardized grape extracts. Biochem Biophys Res Commun, 346: 367-376, 2006.

65. Ungvari Z, Orosz Z, Rivera A, Labinskyy N, Xiangmin Z, Olson S, Podlutsky A, Csiszar A. Resveratrol increases vascular oxidative stress resistance. Am J Physiol Heart Circ Physiol, 292: H2417-424, 2007.

66. Lin AT, Chen MT, Yang CH, Chang LS. Blood flow of the urinary bladder: effects of outlet obstruction and correlation with bioenergetic metabolism. Neurourol Urodyn, 14: 285-292, 1995.

67. Saito M, Wada K, Kamisaki Y, Miyagawa I. Effect of ischemia-reperfusion on contractile function of rat urinary bladder: possible role of nitric oxide. Life Sci, 62: 149-156, 1998.

68. Saito M, Miyagawa I. Direct detection of nitric oxide in rat urinary bladder during ischemia-reperfusion. J Urol, 162: 1490-1495, 1999.

69. Masuda M, Suzuki T, Friesen MD, Ravanat JL, Cadet J, Pignatelli B, Nishino H, Ohshima H. Chlorination of guanosine and other nucleosides by hypochlorous acid and myeloperoxidase of activated human neutrophils. Catalysis by nicotine and trimethylamine. J Biol Chem, 276: 40486-40496, 2001.

70. Toklu HZ, Alican I, Ercan F, Şener G. The beneficial effect of resveratrol on rat bladder contractility and oxidant damage following ischemia/reperfusion. Pharmacology, 78: 44-50, 2006. 